\title{
Assessing the Role of Youth Groups in Community Development in the Nkwanta South Municipality
}

\author{
Jacob Issaka $^{1^{*}(\mathbb{C})}$, Francis Hull Adams ${ }^{2}$, Emmanuel Nomah $^{3}$, Barbara Amoako Kissi ${ }^{4}$ \\ ${ }^{1}$ Jasikan College of Education, Box 14, Jasikan, Ghana \\ ${ }^{2}$ Holy Child College of Education, Takoradi, Ghana \\ ${ }^{3}$ Dambai College of Education, Box 84, Dambai, Ghana \\ ${ }^{4}$ Department of Social Studies, University of Education, Winneba, Ghana \\ Email: jacsak73@yahoo.com
}

Received: 08 December 2021; Revised: 11 January 2022; Accepted: 20 January 2022

\begin{abstract}
The youth is said to be the backbone of every society because of the critical role they play in the community development. The youth, therefore, form the pivot of societal development. This paper assessed the role of youth groups in the community development in Akyode Traditional Area in the Nkwanta South Municipality. The research adopted a mixed-method approach, specifically concurrent triangulation where the researchers employed both the quantitative and qualitative approaches to study a phenomenon at the same time. The simple random sampling technique was employed to select 200 respondents for the study. It was realized that the youth groups play diverse roles including sensitizing members on the importance of education and initiating community development projects. It was also realised that there is a positive relationship between youth development and their role in the community development processes in the area. The study recommends that the competences, attitudes, values and skills of the youth could be further developed through symposia, club meetings, workshops, conferences, seminars and sports and games to enable them to contribute meaningfully towards community development.
\end{abstract}

Keywords: community development, self-help projects, youth groups

\section{Introduction}

The youth is considered as the backbone of every community and they are seen to be the pillars and building blocks of community development. The youth constitute the true wealth and future of every society (Ministry of Youth and Sports, 2010). Therefore, the place and the role of the youth in the community development processes cannot be underestimated. The youth constitute a critical group whose ideologies, vision, capacity, competence, commitment and participation are critical in the community development (Ayertey, 2002). They constitute the potential and active human resources of every community. The advancement of every community to a larger extent relies on the abilities, skills, competences and participatory levels of the youth. It is, therefore, very necessary to involve them in the developmental agenda since development centres around them.

There are multiple definitions of the youth. Ayertey (2002), for example, opines that the youth "refers to young people who fall between the ages of ten and twenty-five years" (p. 336). Yakubu and Abdulai on their part indicated that

Copyright (C2022 Jacob Issaka, et al.

DOI: https://doi.org/10.37256/ser.3120221279

This is an open-access article distributed under a CC BY license

(Creative Commons Attribution 4.0 International License)

https://creativecommons.org/licenses/by/4.0/ 
the youth are young people between the ages of ten and nineteen years. The youth is the period of development from the beginning of puberty to maturity and early adulthood. According to the United Nations, the youth are young people between the ages of 15 and 24 (Hoetu, 2011). The national youth policy of Ghana by the Ministry of Youth and Sports (MYS) (2010) considers the "youth" as people who are between fifteen (15) and thirty-five (35) years. This national definition was informed by the one used by African Youth Charter. Irrespective of the variations, one could describe the youth as the period between childhood and adulthood (Hoetu, 2011; Umeh \& Odom, 2011). They are young people who are energetic, exuberant and full of ambitions.

The youth possess certain qualities which could be used in the community development process. It is, therefore, important that every community put measures in place to harness and utilize the competences of the youth to bring about progress in the community. Young people should be assisted through various community initiatives to equip their with relevant skills, attitudes and values necessary for the community and national development.

Development on the other hand can be defined as the progress made by a nation to overcome its social, political and economic problems in order to improve the quality of life of the people through the effective mobilization of its resources (Ayertey, 2002). Development can also be defined as bringing about meaningful social change that allows people to achieve the quality of life. It must be pointed out that development is a process rather than an outcome. It is a changing process from one state to another which is normally a positive one, that is, an improvement of a sort. Human Development Index (HDI) measures development using tools and indicators. These include life expectancy, health, education and income (UNDP, 2018). Community development involves a transformation in all aspects of the community.

The rationale of community development is to bring improvement that will lead to better standards of living or quality of life. The youth have diverse roles to play in community development. Their skills, knowledge, competence, energy and capabilities support the process of community development. The youth have good dreams which could be harnessed for community development. The development of communities depends on the potential, competences, commitment and participation of the youth.

It is not uncommon to hear that the youths are the future leaders and the backbone of society. It could, therefore, be indicated that the role of the youth in community development is very crucial; hence a lot of people look up to them for active leadership, participation, loyalty, selfless service, patriotism and discipline. The youth generally forms the greater proportion of the active human resource. They have some qualities, which include the ability to initiate the process of social changes (Oadire, 2010). The youth have a key role to play in the development of the nation in general and their communities in particular, especially with the current pressure on the national government.

The role of the youth in community development has necessitated the government of Ghana to initiate and implement certain policies aimed at ensuring youth development. In addition, the government of Ghana has also initiated certain programmes in various communities to bring about socioeconomic development. It should be noted, however, that the cost of implementing these programmes to bring about community development has been rising too fast in relation to the government budget. The government continues to borrow a huge amount of money to promote community development resulting in high national debt. It is for this reason that the idea of self-help development projects has become vital. Government and Non-governmental organizations (NGO's) mostly go to the aid of communities who initiate self-help projects. Therefore, most communities have initiated projects in order to improve their welfare and bring about social and economic development in their respective communities.

However, most community development processes tend to overlook the role and potentials of the youth (Udensi et al., 2013; Umeh \& Odom, 2011). The potentials of the youth have, therefore, been relegated to the background when it comes to initiating and implementing community development programmes and projects in most communities. This could emanate from the gerontocracy nature of our African society over the years, where the assumption is that wisdom to some extent is equated to old age. However, it should be noted that wisdom is not and cannot all the time be equated to old age. It is a common fact that the majority of the youth across the globe have exhibited excellence in wisdom and maturity when it comes to contributing to community development (Umeh \& Odom, 2011).

The role of the youth in community development has attracted attention in current research literature (Udensi et al., 2013; Lynn, 2005; Okwusi, 2008). Research suggests that the youth are playing important roles in the development of their communities (Sherrod et al., 2002). There are many publications on the role of the youth in community development. On the role of the youth, Ayertey (2002) for instance, stated that the youth help in planning and initiating 


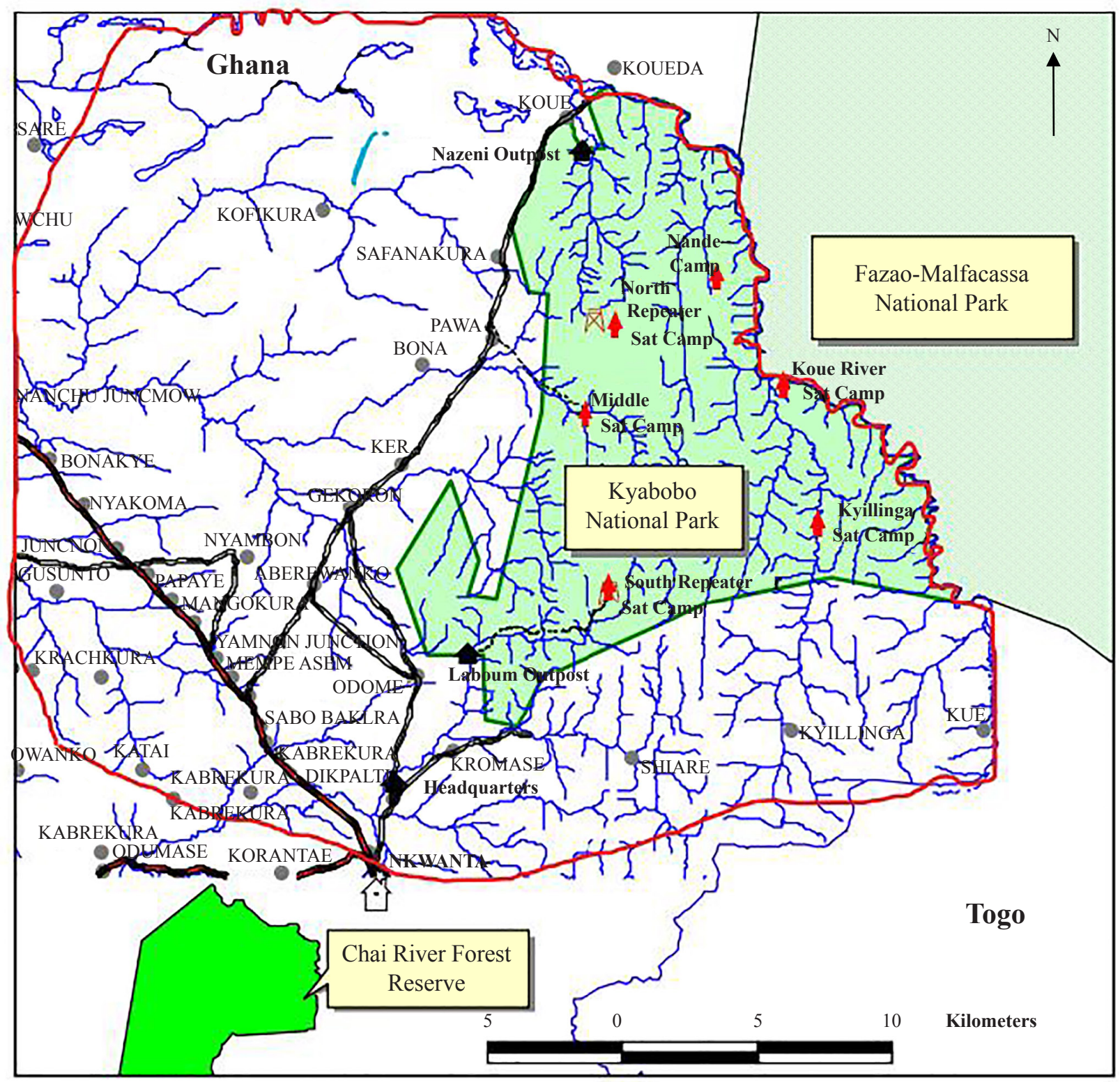

Key

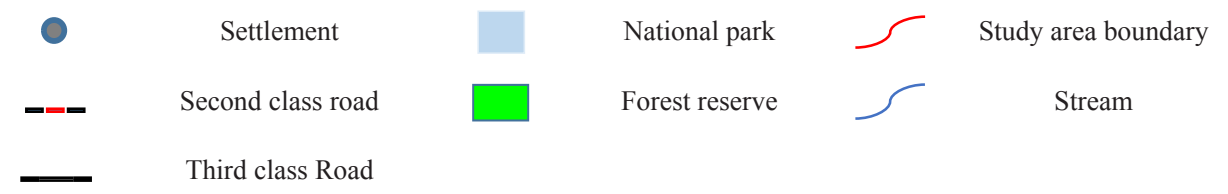


There are few studies that cover the role of youth in development in Ghana. Most of these studies were mainly on the General roles of the youth in the national development or nation-building. Hoetu (2011) for instance looked at mainstreaming youth in the national development. His paper gives extensive elaborations on benefits derived from mainstreaming youth in the national development and challenges facing the youth. Hoetu could have obtained specific information on these issues if he targeted specific youth groups who may have relevant information. Another extensive work on youth participation was done by Gyampo and Obeng-Odoom (2013). However, their study talks extensively on diverse processes and dynamics of youth participation in pre and post-colonial eras and teases out implications of these in the national development in Ghana. These studies did not assess the role of the youth in the community development. These studies also did not look at youth groups. It is against this background that this study was conducted to assess the role of youth groups in the community development. Specifically, this study sought to find out the contributions of youth groups in the development of Akyode communities in the Nkwanta South Municipality.

The Akyodes are one of the guans who are found at the central and north-eastern part of the Nkwanta South Municipality (as in Figure 1). All the Akyode communities have youth groups that are supposed to spearhead the development and deal with youth issues. These youth groups are called Akyode Youth Associations (AYA) with different branches. These youth groups pose significant potential for the development of their respective communities and the nation at large and as such much is expected from them. Issues concerning development are most often put at the doorstep of these youth groups. These youth groups are expected to deal with a lot of issues ranging from social to political. Such youth groups should be provided with the needed resources to enable them to contribute to the economic, social, and cultural advancement of communities (Ministry of Youth and Sports, 2010). However, no research has been conducted to assess the role of these youth groups in the development of their communities.

It must be noted that the role of youth towards community development depends on many different factors (Edberg, 2008). One of such factors could be youth empowerment and development. According to Adesope (2007), there is a need for effective training for the youths for their proper impact to be felt in their communities. According to Umeh and Odom (2011), despite various programmes of government involving the youth in various communities, the contribution of the youth is minimal because they lack the capacity. Also despite the abundance of youth in most communities in Ghana, the communities are still poor in the areas of youth support for the needed development (Nkwede \& Nwovu, 2014). The seemingly increased moral decadence and other social vices among the youth are becoming worrisome. There seems to be a lack of data on the process of youth empowerment and development. Inasmuch as these youth groups occupy prestigious positions in the Akyode Traditional Area in the Nkwanta South Municipality, little seems to be known about their empowerment and support for community development. With the increasing challenges facing the youth in the area coupled with deviant and immoral behaviours among the youth, a lot of questions have been raised on the process of youth empowerment development in the Municipality. Youth can contribute meaningfully to the community development when their skills, attitudes and values are developed (Ministry of Youth and Sports, 2010). Therefore, it becomes pertinent to find out strategies for youth empowerment and development. Though much research has been done on youth, no research has tried to determine the relationship between youth development and the role of youth groups in the community development. This study seeks to determine the relationship between youth development and the contributions of youth groups in the community development.

\section{Conceptual framework}

There are certain variables that influence the role of the youth in the community development. The role of youth depends on the capacity of the youth (Edberg, 2008). In short, positive youth contribution emphasizes the capacity and potential of the youth. Some studies have tended to look at the youth in relation to social vices such as smoking, sexual promiscuity and drug abuse. The current study presents a fundamental shift from some conceptualizations of youth as deviants, dangerous, and "problems to be managed. It does not, however, see youth development and the contribution of the youth as the absence of negative or risky behaviors such as drug use, truancy and delinquency (Lerner, 2005; Lerner et al., 2013). Many studies on the youth prior to the early 1990s focused mostly on irresponsible behaviors of the youth and reducing risk exposure (Lerner, 2005).

One of the conceptual models relevant to this study is that of Benson and Saito (2001). Benson and Saito (2001) describe four concepts that provide opportunities for healthy youth development. They are programmes, organizations, 
socializing systems, and communities.

Programmes are activities and processes, normally led by adults and designed to address certain objectives and youth outcomes. A programme can be considered a youth development programme when it intentionally integrates experiences to address the positive development of young people. This category includes a range of programmes that may include highly structured programmes in the form of a curriculum with clear activities for youth development. This study believes that youth groups could contribute meaningfully to community development if useful programmes for their empowerment and development are organized.

Organizations provide youth with development opportunities in which a wide variety of activities and relationships are designed to improve the well-being of youth. Examples include school-based clubs and associations and cocurriculum activities such as sports and field trips. Some of the youth organizations include Catholic Youth Association (CYO), Boy Scouts, Girl Scouts, Young Men's Christian Association (YMCA), Young Women's Christian Association (YWCA). These kinds of clubs and associations can organise a wide range of activities for youth's development. Youth participate more in the community development when they mobilize themselves in groups or associations.

Socialization agencies also play important roles in youth development. These include schools, families, neighborhoods, religious institutions, museums, and libraries. The exposure given by these agencies improves their knowledge, skills, attitudes and values which to a large extent help the youth contribute to community development.

Community is not only the geographic place within which programmes, organizations, and systems intersect but also the social norms, relationships, resources, and informal settings that dramatically inform human development-both directly and indirectly.

Benson and Saito's (2001) model is relevant to this study because the contribution of the youth towards community development depends on the environment in the youth find themselves. An enabling environment for youth development includes the structures of the community including the norms as well as socializing systems, youth organizations and programmes. The four concepts that provide opportunities for healthy youth development are illustrated in Figure 2.

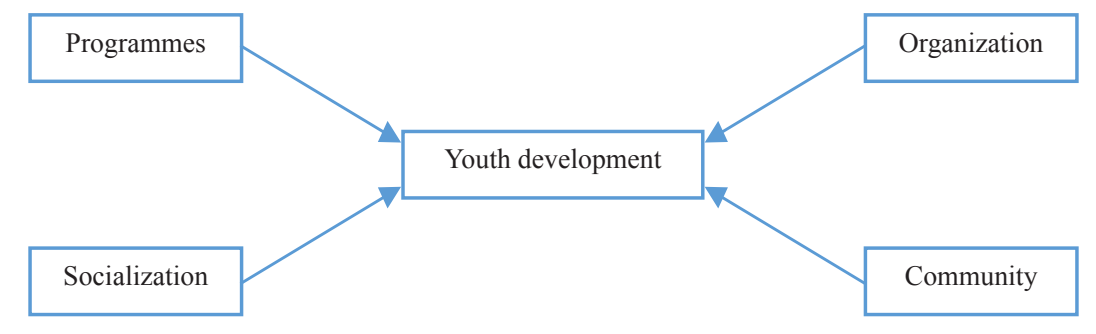

Figure 2. Adapted Benson and Saito's model

The present study was designed to achieve the following objectives.

1. To assess the role of the youth groups in community development in Nkwanta South Municipality.

2. To find out ways of promoting youth development in the Nkwanta South Municipality.

3. To determine the relationship between youth development and the contribution of youth groups to community development.

4. To determine the challenges facing youth groups in the Nkwanta South Municipality.

Research questions:

1. What are the roles of youth groups in community development in Nkwanta South Municipality?

2. What are the ways to promote youth development in the Nkwanta South Municipality?

3. What relationship exists between youth development and their contributions towards community development?

4. What are the challenges facing youth groups in the Nkwanta South Municipality? 


\section{Methods}

The transformative paradigm was adopted by the study. The transformative paradigm denotes a family of research designs that are influenced by various philosophies and theories with a common theme of transforming communities through group action. The transformative paradigm adopts the stance that social reality is historically bound and constantly changing, depending on social, political, cultural and power-based factors (Mertens, 2009). This paradigm is used because the researchers believe that knowledge is true, which can be put into practice to empower and transform the lives of the people (Mertens, 2009). This study adopted the mixed-method approach as it satisfies the conditions explained by Greene (2007). Greene (2007) defines mixed-method research as the type that uses both quantitative and qualitative research approaches for broad in-depth comprehension and justification. Simply put, a mixed methodology is a blend of both qualitative and quantitative methods of data collection for the same study. Creswell and Clark (as cited in Almeida, 2018, p. 138) acknowledged that "mixed-method research is a research design (or methodology) in which the researcher collects, analyzes, and mixes (integrates or connects) both quantitative and qualitative data in a single study or a multiphase program of inquiry". Similarly, "mixed-method inquiry is an approach to investigating the social world that ideally involves more than one methodological tradition and thus more than one way of knowing" Greene, (as cited in Almeida, 2018, p. 138). This method was chosen for the study because of its advantages of exposing the researcher to a variety of data (rich and comprehensive data) needed to draw objective conclusions to findings (Creswell, 2003). Additionally, one of the reasons for using the mixed method for a study is to complement one set of results with another, to expand a set of results, or to discover something that would have been missed if only a quantitative or a qualitative approach is employed.

There are six types of mixed-method research design according to Creswell (2003). These include sequential explanatory; sequential exploratory; sequential transformative; concurrent triangulation; concurrent nested; and concurrent transformative. The study adopted the research concurrent triangulation. Creswell (2003) posits that the term 'concurrent' indicates that both qualitative and quantitative data are being collected at the same time. The concurrent triangulation method was used because it allows the researcher to collect and analyse data using both quantitative and qualitative approaches at the same time.

All the youth in the Akyode Traditional area of the Nkwanta South Municipality constitute the population. The simple random sampling technique was used to select two hundred respondents. This technique was used because of the researchers' equal chance for all members of the youth groups in the Akyode communities. In addition, the purposive sampling technique was used to select the leaders of youth groups in the area. The main instruments for data collection were structured questionnaires and interviews. The questionnaire was used because it helped to obtain reliable information and also ensured a wider coverage (Issaka et al., 2021; Kwabia, 2006). The Likert scale was commonly used. The questionnaire comprised four sections which include the demographic information, contributions of youth groups towards community development, strategies to develop the youth and challenges facing youth groups. Interviews were also conducted to obtain detailed information on the problem being researched. The data were analysed using descriptive and correlational statistics.

\subsection{Validity and reliability of the instrument}

The questionnaire and the interview guide were edited by experts before administered. The experts read through the questions to determine whether their contents were adequate and relevant. They also helped to identify ambiguities. The instruments were reviewed and this helped to achieve validity of the instruments.

Reliability on the other hand measures consistency, correctness and repeatability of data (Chakrabartty, 2013). Cronbach's alpha was used to determine the reliability using Statistical Package for Social Science (SPSS) version 21. Field (2005) posits that Cronbach's alpha calculated the internal consistency and alpha coefficient of 0.50 and above shows strong reliability. The Cronbach's alpha for all the items was 0.792 or higher indicating very high-reliability levels as shown in Table 1 . 
Table 1. Reliability coefficients for the role of youth and youth development

\begin{tabular}{|c|c|}
\hline Items & Cronbach's Alpha $(\alpha)$ \\
\hline Mobilization of funds for self-help projects & 0.825 \\
\hline Sensitization on issues of national concern & 0.812 \\
\hline Promotion of peace and order & 0.788 \\
\hline Assisting members to get jobs & 0.797 \\
\hline Initiating self-help projects & 0.792 \\
\hline Provision of labour for self-help project & 0.794 \\
\hline Mobilizing people for social activities & 0.799 \\
\hline Resolving conflicts & 0.797 \\
\hline Provision of leadership for community projects & 0.802 \\
\hline Organization of sports and games & 0.797 \\
\hline Provision of education & 0.830 \\
\hline Capacity building workshop & 0.798 \\
\hline Seminars on the role of the youth & 0.807 \\
\hline Attending conferences on youth-related issues & 0.794 \\
\hline Training on leadership skills & 0.807 \\
\hline
\end{tabular}

\section{Results}

The presentation and discussion of results were based on the research objectives. In all, 200 respondents were involved in the study. On gender, it was realized that $122(61 \%)$ were males while $78(39 \%)$ were females. This is shown in Figure 3.

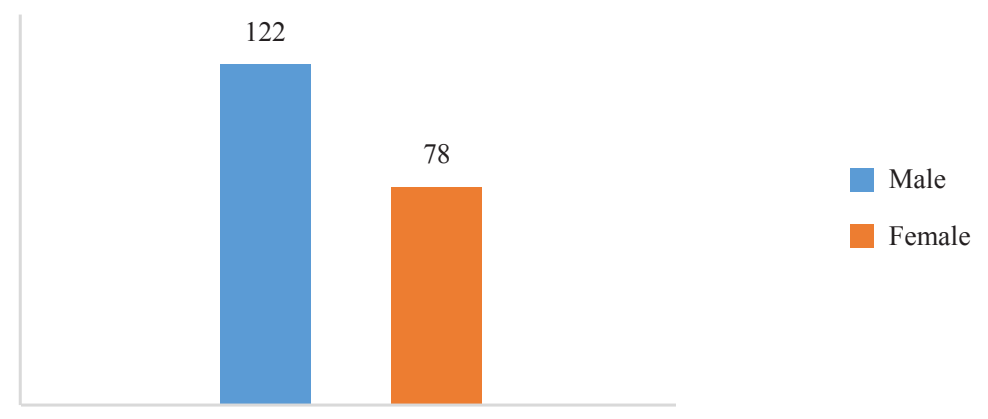

Figure 3. Gender of respondents

The first objective of the study was to assess the role of the youth groups in community development in Nkwanta 
Municipality. Community development depends on the active participation of its members including the youth. Brennan et al. (2006) stated that active involvement of the youth in community development empowers them to be problemsolvers, decision-makers, and committed leaders who will lead community development efforts in the future. The study, therefore, sought to assess the contributions of youth groups in community development in the Nkwanta South Municipality since this is crucial for the advancement of society. Respondents were asked to evaluate the contributions of youth groups in the municipality using a Likert scale of 1-5 where 1 stands for strongly agree, 2 for agree, 3 for somehow agree, 4 for agree and 5 for strongly agree. Table 2 presents the evaluation of the contributions of youth groups towards community development.

Table 2. Contributions of youth groups in community development in Nkwanta Municipality

\begin{tabular}{cccc}
\hline Items & Mean & $\%$ & Remarks \\
\hline $\begin{array}{c}\text { Mobilization of funds for self-help projects } \\
\text { Sensitization on issues of national concern }\end{array}$ & 3.77 & 75.4 & Very good \\
Promotion of peace and order & 4.01 & 80.2 & Excellent \\
Initiating self-help projects & 4.04 & 80.8 & Excellent \\
Provision of labour for self-help project & 3.97 & 79.4 & Very good \\
Mobilizing people for social activities & 3.79 & 75.8 & Very good \\
Resolving conflicts & 3.95 & 79.0 & Very good \\
Provision of leadership for community projects & 3.90 & 78.0 & Very good \\
General contributions of the youth (mean of mean) & $\mathbf{3 . 9 3}$ & $\mathbf{7 8 . 6}$ & Very good \\
\hline
\end{tabular}

Key for Remarks:

2.5: Unsatisfactory; 2.5-2.99: Satisfactory; 3.00-3.49: Good; 3.5-3.99: Very Good; 4.00-5.00: Excellent Source: Field data, 2021

Table 2 shows that the general contribution of youth groups in community development in Nkwanta South Municipality was very good. Their contributions in most of the variables identified as contributions of youth groups were very good. Areas that their contributions were very good to include mobilization of funds for self-help projects, sensitization on issues of national concern, provision of labour for self-help projects, mobilizing people for social activities, resolving conflicts and provision of leadership for community projects. According to the results, the contributions of youth groups in the areas of initiating self-help projects (4.04) and promotion of peace and order (4.01) could be described as excellent.

Some of the respondents during the interview also mentioned some important contributions of youth groups in the Nkwanta South area. Most of them mentioned sensitization on the importance of education, organization of sports activities, assisting in initiating projects, planning and implementing activities during the yam festival in the area.

One of the respondents reacting to the role of the youth groups said:

We normally meet to plan on what to do to develop our communities. As a youth, we also have a role to play towards the development of our community. [Eeemm], you know, the development of the community lies on the contribution of all and sundry. As youth groups, we educate both the youth and their parents on the importance of education. We advise them to eschew all forms of social vices and pre-marital sex since these can jeopardize their education. We have those in charge of education who go to schools and communities to talk about the importance of education. We also organize talks on activities to promote peace and development. (\#participant 4; March 2021). 
Another respondent also indicated that:

We try to organize ourselves to embark on activities towards the development of our community. I could remember, every year, we plan the activities for our yam festival including the projects to embark on by the community. We also promote our cultural heritage during the festival. We undertake activities to promote our cultural heritage. We also educate the youth to take their education seriously (\#participant 2; March, 2021).

One of the respondents also had this to say on the role of the youth in community development:

You know, we formed youth groups to undertake activities to promote peace and development. You know, without peace, there cannot be development. We organize peace talks in the various communities. Though we are not able to do as expected, we have been doing our bits. We educate our members on the importance of education and the history of our community. We inspire our members to take up leadership positions. We undertake a series of activities during the yam festival. We organize sports competitions and this helps to promote peace and unity in the area. You know, we also play an important role in Guan Congress. We send a delegation any time the Guan Congress is organized (\#participant 5; March 2021).

The data on the contributions of the youth groups towards community development were subjected to descriptive statistics analysis which presents the sample population, minimum, maximum, mean, standard deviation, skewness and kurtosis. This is necessary to see the distribution and dispersion in order to see whether the data could be subjected to parametric statistical analysis. The result of the descriptive analysis is summarised in Table 3.

Table 3. Descriptive statistics on the contributions of youth groups

\begin{tabular}{|c|c|c|c|c|c|c|c|}
\hline Items & $\mathrm{N}$ & Min & Max & Mean & SD & Skewness & Kurtosis \\
\hline Mobilization of funds for self-help projects & 200 & 1 & 5 & 3.77 & 0.950 & -0.793 & 0.593 \\
\hline Sensitization on issues of national concern & 200 & 1 & 5 & 3.99 & 1.067 & -0.814 & -0.105 \\
\hline Promotion of peace and order & 200 & 1 & 5 & 4.01 & 1.114 & -0.955 & -0.105 \\
\hline Initiating self-help projects & 200 & 1 & 5 & 4.04 & 0.942 & -0.971 & 0.739 \\
\hline Provision of labour for self-help project & 200 & 1 & 5 & 3.97 & 1.013 & -0.812 & -0.252 \\
\hline Mobilizing people for social activities & 200 & 1 & 5 & 3.79 & 1.012 & -0.950 & 0.784 \\
\hline Resolving conflicts & 200 & 1 & 5 & 3.95 & 0.917 & -0.911 & 0.803 \\
\hline Provision of leadership for community projects & 200 & 1 & 5 & 3.90 & 1.173 & -0.749 & -0.805 \\
\hline
\end{tabular}

Source: Field data, 2021

It could be observed from Table 3 that mobilization of funds for self-help projects records a mean of 3.77 with a standard deviation of 0.950 , skewness of -0.793 and kurtosis of 0.593 . Initiating self-help projects has the highest mean of 4.04 with a standard deviation of 0.942 , skewness of -0.971 and kurtosis of 0.739 . The standard deviation of the various items shows the closeness of the responses.

It could be seen from Table 3 that, the values of the skewness and kurtosis for all the items fall within -1 and +1 . This shows that the data is normally distributed and could be subjected to parametric statistical analysis (Kim, 2013). Table 3 also shows that the skewness for all the items is negative. A negative skew value indicates that the tail on the left side of the distribution is longer than the right side and the bulk of the values lie to the right of the mean. The kurtoses of the four of the variables are positive while the other four are negative. Kurtosis is a measure of the peakedness of a 
distribution. A positive kurtosis (leptokurtic distribution) mean a high peak, while distributions with negative kurtosis (platykurtic distribution) means a flat-topped curve (Kim, 2013).

Another important objective for the study was to find out the strategies for youth development in the Nkwanta Municipality. The respondents were asked to indicate their level of agreement on certain strategies to develop the youth and their responses are displayed in Table 4.

Table 4. Descriptive analysis on strategies for youth development

\begin{tabular}{ccccccccc}
\hline Items & $\mathrm{N}$ & Min & Max & Mean & $\%$ & SD & Skewness & Kurtosis \\
\hline Organization of sports and games & 200 & 1 & 5 & 3.81 & 76.2 & 0.896 & -0.750 & 0.818 \\
Seminars on the role of the youth & 200 & 1 & 5 & 3.24 & 64.6 & 1.257 & -0.205 & -0.966 \\
Capacity building workshop & 200 & 1 & 5 & 3.77 & 75.4 & 1.094 & -0.897 & 0.320 \\
Attending conferences on youth related issues & 200 & 1 & 5 & 3.78 & 75.6 & 1.017 & -0.927 & 0.824 \\
Provision of education & 200 & 1 & 5 & 4.29 & 85.8 & 0.722 & -0.601 & -0.541 \\
Leadership training & 200 & 1 & 5 & 4.01 & 80.2 & 1.106 & -0.888 & -0.289 \\
\hline
\end{tabular}

Source: Field data, 2021

Table 4 shows that the mean distribution ranges from 3.24 in the case of seminars on the role of the youth to 4.29 in the case of provision of education. It could be realized that most of them agreed that the organization of sports and games, seminars, workshops, conferences, education and training are key strategies for youth development. Table 4 also shows that the standard deviation ranges from 0.722 for the provision of education to 1.257 in the case of seminars. The skewness of all the items is in the negative showing negative skewness. This shows that most of the values lie to the right of the mean. That means that most of the respondents either agreed or strongly agreed to the items. Three of the kurtoses are positive (high peaks) and three are also negative (flat peaks).

The third objective was to determine the relationship between youth development and the contribution of youth groups to community development. Before the correlation analysis, all the different variables on the contributions of the youth in community development were computed into a target variable and the mean was calculated and this mean became the dependent variable. In the same way, the different variables under youth development were also computed into a target variable and the mean calculated and this became the independent variable.

\subsection{Correlation analysis results}

To analyse the relationship, the Pearson correlation analysis was conducted to establish the correlation between youth development and the contribution of youth to community development. The result of the analysis is presented in Table 5.

The correlation between youth development and contribution of youth is 0.568 and this correlation is significant at a one percent significance level. This means that youth development has a positive and significant relationship with the contributions of the youth. This further implies that if there is improvement in youth development, their contribution towards community development will also improve. It is based on this analysis that the observed model was developed.

The observed model shown on Figure 4 indicates that youth groups can effectively contribute towards community development when the capacity of the youth is developed.

Youth groups have a lot of roles to play in community development but they may be unable to do so because of certain challenges they may encounter. The responses from the subjects on challenges facing youth groups are displayed in Table 6. 
Table 5. Correlation analysis results

\begin{tabular}{lccc}
\hline \multicolumn{2}{c}{ Variables } & contribution of the youth & Ways promoting youth development \\
\hline & Pearson Correlation & - & $0.568^{* *}$ \\
Contribution of the youth & Sig. (2-tailed) & - & 0.000 \\
$\mathrm{~N}$ & - & 200 \\
Promoting youth development & Pearson Correlation & $0.568^{* *}$ & - \\
& Sig. (2-tailed) & 0.000 & - \\
& N & 200 & \\
& $* *$. Correlation is significant at the 0.01 level (2-tailed).
\end{tabular}

Source: Field data, 2021

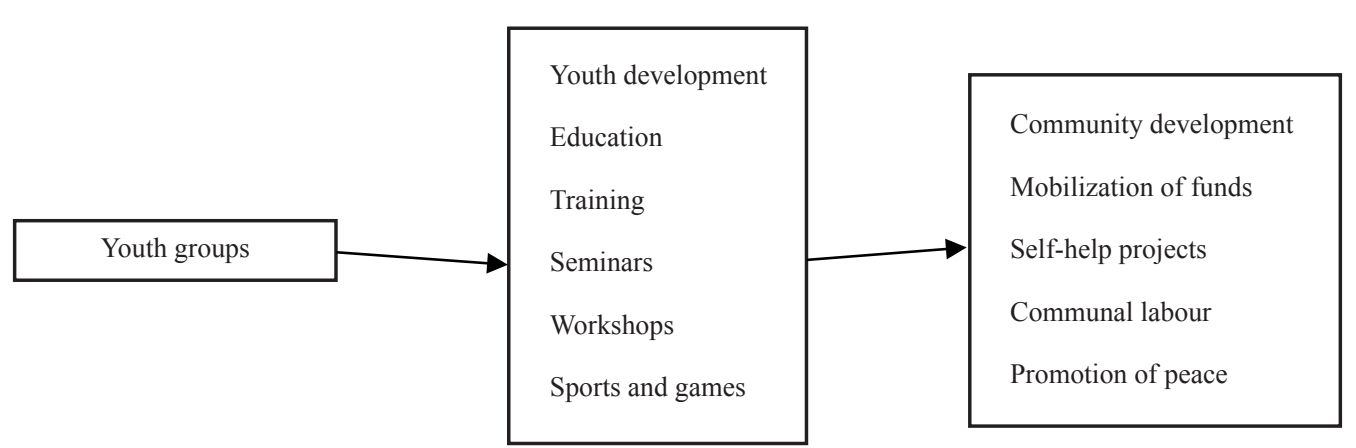

Figure 4. Observed model of youth and community development

Table 6. Challenges facing youth groups

\begin{tabular}{|c|c|c|c|c|c|c|c|c|c|c|}
\hline \multirow[t]{2}{*}{ Challenges } & \multicolumn{2}{|c|}{ SA } & \multicolumn{2}{|c|}{ A } & \multicolumn{2}{|c|}{ NS } & \multicolumn{2}{|c|}{$\mathrm{D}$} & \multicolumn{2}{|c|}{ SD } \\
\hline & $\mathrm{F}$ & $\%$ & F & $\%$ & $\mathrm{~F}$ & $\%$ & $\mathrm{~F}$ & $\%$ & F & $\%$ \\
\hline Inadequate funds & 133 & 66.5 & 67 & 33.5 & & & & & & \\
\hline Poor leadership & 14 & 7 & 104 & 52 & & & 75 & 37.5 & 7 & 3.5 \\
\hline Conflict within the associations & 11 & 5.5 & 122 & 61 & & & 38 & 19 & 29 & 14.5 \\
\hline Lack of commitment on the part of members & 142 & 71 & 58 & 29 & & & & & & \\
\hline Lack of recognition & 8 & 4 & 20 & 10 & & & 172 & & 86 & \\
\hline Lack of effective rules and regulations & 22 & 11 & 109 & 54.5 & & & 61 & 30.5 & 8 & 4 \\
\hline Lack of time & 98 & 49 & 63 & 31.5 & & & 39 & 19.5 & & \\
\hline Lack of accountability & 44 & 22 & 118 & 59 & & & 38 & 19 & & \\
\hline
\end{tabular}

Source: Field data, 2021 
Table 6 shows that youth groups in the Akyode area face some challenges in the performance of their roles. It could be seen from the table that the majority of the respondents agreed to most of the items as challenges facing youth groups except lack of recognition. The table shows that all the respondents either agreed or strongly agreed that inadequate funds and lack of commitment on the part of members are challenges facing youth groups. It could also be seen that $52 \%$ and $61 \%$ respectively agreed that poor leadership and conflicts within the associations are challenges facing youth groups in the area. The table also shows that $59 \%$ agreed that lack of accountability is a challenge facing youth groups while $49 \%$ strongly agreed that lack of time is a challenge. These challenges can affect the effective contribution of youth groups in community development.

The results from the interview also reveal a lot of challenges facing youth groups in the area. One of the respondents indicated that:

For the problems, they are many. In the first place, most of us do not see the reasons why they should join the youth association. They don't see the benefits of joining the associations. Even though the association is compulsory for all the youth in the town, most of them are not ready to participate in activities organized by the association. When you organize meetings only a few will attend. When you ask them to pay money for projects most of them will not pay. The youth are not committed to the association. It is only by name, it is not functioning and/or active at all. You will only see this association during our yam festival. After that, the association does not do anything (\#participant 1; March 2021).

Another respondent also indicated that:

I think the major challenge facing our youth association is effective leadership. For associations to perform the needed functions, everything depends on the leadership. Here people only struggle for a leadership position because of personal interest and not for development. Another challenge related to the commitment on the part of members. Most of us are attending school and we are not always around to attend meetings and embark on activities we planned to do. It is also difficult to raise money to carry out activities (\#participant 4; March 2021).

In addition, the respondents had this to say on challenges facing youth groups:

Our youth association has many problems. We don't like coming to meetings and it is only at meetings that you can plan towards development. If you ask them to contribute money too, most of them will say they are students and they don't have money. Without money, there is nothing you can do. Money is the fuel of every engine. We also don't have effective rules to compel the youth to join the association (\#participant 3; March 2021).

\subsection{Discussions}

The development of a community highly depends on the contributions of the individuals and groups in that community (Akinbile et al., 2006). Therefore, youth groups have diverse contributions to make towards the development of the community. This is why Brennan et al. (2006), stated that active involvement of the youth in the community development process leads to community development. Youth groups are expected to undertake programmes to promote peace and order (Umeh \& Odom, 2011). They are also supposed to undertake sensitization on issues of national concern and provide labour for self-help projects. The youth groups can also contribute to community development through mobilization of people for social activities, resolving conflicts and provision of leadership for community projects. The youth are also expected to initiate and mobilise funds for self-help projects (Ayertey, 2002; Udensi et al., 2013).

The development of human resources has a significant impact on national development. This is why nations spend a huge amount of resources on their human resource development. Youth development is very crucial in community development. The correlation analysis shows a positive relationship between youth development and the contributions of the youth. Therefore, communities need to provide diverse programmes that will promote youth empowerment and development (Gyampo \& Obeng-Odoom, 2013). The capacities, competences and abilities of the youth could be 
developed through the organization of sports and games, seminars, workshops, conferences, education, and training. Youth development could be accelerated when they are in groups such as scout groups, social clubs and religious youth groups (National Academy of Sciences, 2005). There is, therefore, the need to promote youth development through education, training (Larson, 2000), organization of seminars, workshops and sports and games to enable the youth to contribute meaningfully towards community development (Gyampo \& Obeng-Odoom, 2013).

In life, most people are unable to achieve their potential to the fullest because of certain challenges. Challenges facing the youth groups could affect the effectiveness and usefulness of youth groups. Inadequate funds, lack of effective leadership and commitment can affect the organization of youth groups and for that matter their contribution towards community development. Many studies have attested to the fact that challenges facing the youth affect their contributions towards community development. Many young people remain uneducated and unskilled to be considered in the job market. This phenomenon coupled with limited employment opportunities is largely responsible for the high unemployment and underemployment rate (Hoetu, 2011). Such challenges result in drug abuse and aggressive behaviours (Ayertey, 2002) which affect the contribution of youth towards community development.

The youth are the backbone of every economy. Youth groups are very important groups that help to draw the attention of the government and other agencies to issues affecting community development. Youth groups also organize their members to plan and implement programmes for community development (Ayertey, 2002). There is, therefore, the need to adopt certain ways to make youth groups effective. Some of the ways to make youth groups contribute meaningfully towards community development include effective leadership, support from adults, talks on the importance of youth groups and reliable source of funds for youth groups. This agrees with Ayertey when he indicated that the youth should form clubs where they could be given training and education. Larson (2000) also indicated that communities should organise capacity building for youth groups in leadership and skills needed for the world of work as these are necessary for their involvement in community development.

\section{Conclusion}

The contribution of youth groups in community development in the Nkwanta South Municipality is very good. There is a positive correlation between youth development and their contributions towards community development. The correlation coefficient between youth development and contribution of youth is 0.568 and this correlation is significant at a one percent significance level. Communities should put in place mechanisms that will promote youth development to enable them to contribute meaningfully to community development. Challenges such as poor leadership, lack of accountability, lack of funds, and lack of commitment to group activities have bedeviled the contribution of the youth groups in community development. For effective contributions of youth groups in community development, there is the need for communities to address the challenges facing youth groups such as poor leadership and lack of funds to enable youth people to contribute meaningfully towards community development.

\subsection{Recommendations}

Measures should be put in place to address the various challenges facing the youth in general and youth groups in particular. The youth should be encouraged to join youth associations to engage in activities for their empowerment. The youth empowerment programmes should equip them with competences, knowledge, attitudes, values and skills. This could be done through capacity training, education, seminars and workshops. They should be given the needed support including the provision of resources required to enable them to contribute to the economic, social, and cultural advancement of their communities. Communities should also put in place measures to address unemployment, low level of education, use of hard drugs and alcoholism among the youth. The provisions in the Ministry of Youth and Sports (2010) should be implemented. All these will go a long way to empower the youth to contribute meaningfully towards community development. Future researchers could look into the role of local authorities in promoting youth development. 


\section{Conflict of interest}

The authors declare no competing financial interest.

\section{References}

Adesope, O. M. (2007). Mobilization of youth for proper impact in community. Expart publishing press: Onitsha, Anambra State.

Akinbile, L. A., Ashimolowo, O. R., \& Oladoja, M. A. (2006). Rural youth participation in infrastructural development of Ibarapa East local government area of Oyo State. Nigerian Journal of Rural Sociology, 6(1-2), 40-48.

Almeida, F. (2018). Strategies to perform a mixed methods study. European Journal of Educations Studies, 5(1), 137151. https://doi.org/10.5281/zenodo.1406214

Ayertey, I. (2002). Mastering social studies for senior high schools. Accra, Ghana : Excellent Publishing \& Printing.

Benson, P. L., \& Saito, R. N. (2001). The scientific foundations of youth development. In P. L. Benson \& K. J. Pittman (Eds.), Trends in youth development: Visions, realities, and challenges (pp. 135-154). Norwell, MA: Kluwer Academic.

Brennan, M. A., Barnett, R. V., \& Lesmeister, M. K. (2006). Enhancing local capacity and youth involvement in the community development process. Community Development, 38(4), 13-27. https://doi.org/10.1080/15575330709489816

Chakrabartty, S. N. (2013). Best split-half and maximum reliability. IOSR Journal of Research \& Method in Education, $3(1), 1-8$.

Creswell, J. W. (2003). Research design: Qualitative, quantitative and mixed methods approaches (4th ed.). Thousand Oaks, CA: Sage.

Edberg, M. C. (2008). Development of Latin America/Caribbean adolescent well-being indicators: Background and proposed indicators. Report for UNICEF-LAC region, Panama City, Panama.

Field, A. P. (2005). Discovering statistics using SPSS. California: Sage Publications Inc.

Gyampo, R. E. V., \& Obeng-Odoom, F. (2013, March). Youth participation in local and national development in Ghana: 1620-2013. The Journal of Pan-African Studies, 5(9), 129-150.

Gayle, V. (1998). Structural and cultural approaches to youth: Structuration theory and bridging the gap. Youth and Policy, 61, 59-72

Greene, J. C. (2007). Mixed methods in social inquiry. John Wiley \& Sons.

Hoetu, P. (2011). Mainstreaming youth: the key to effective youth development in Ghana. Accra: Friedrich-EbertStiftung. https://library.fes.de/pdf-files/bueros/ghana/10500.pdf

Issaka, J., Adams, F. H., Gyimah, E., \& Kissi, B. A. (2021). Impact of child labour on children's academic activities in Krachi east district. Asian Journal of Education and Social Studies, 18(2), 33-42. https://doi.org/10.9734/ ajess/2021/v18i230439

Kim, H. Y. (2013). Statistical notes for clinical researchers: Assessing normal distribution (2) using skewness and kurtosis. Restor Dent Endod, 38(1), 52-54. https://doi.org/10.5395/rde.2013.38.1.52

Kwabia, K. (2006). Theory in social research: The link between literature and observation. Accra: Woeli Publishing Services.

Larson, R. W. (2000). Toward a psychology of positive youth development. American Psychologist, 55(1), $170-183$. https://doi.org/10.1037/0003-066X.55.1.170

Lerner, R. M., Napolitano, C. M., Boyd, M. J., Mueller, M. K., \& Callina, K. S. (2013). Mentoring and positive youth development. In D. L. DuBois \& M. J. Karcher (eds.). Handbook of Youth Mentoring (pp. 17-28). California: Sage Publications.

Lerner, R. M. (2005). Promoting positive youth development: Theoretical and empirical bases. Paper prepared for the Workshop on the Science of Adolescent Health and Development, National Research Council, Washington, DC. Washington, DC: National Academy of Sciences.

Lynn, A. (2005). Youth using research: Learning through social practice, community building, and social change. New Directions for Youth Development Summer, 106, 39-48. https://doi.org/10.1002/yd.117

Mertens, D. (2009). Transformative research and evaluation. New York: The Guilford Press.

Ministry of Youth and Sports. (2010). National youth policy of Ghana. Accra: Ministry of Youth and Sports.

National Academy of Sciences. (2005). Community programs to promote youth development. The National Academies. https://www.literacymn.org/sites/default/files/youth_development_brief.pdf 
Nkwede, J. O., \& Nwovu, A. S. (2014). World bank assisted community development programme: A study of rural areas in ebonyi state, Nigeria. Journal of Political Science and Public Affairs, 2(1). https://doi.org/10.4172/23320761.1000110

Oadire. (2010). The role of youths in community development Samphina Academy. https://iproject.com.ng/sociology/ the-role-of-youths-in-community-development/index.html.

Okwusi, M. C. (2008). Youths attitude to rural development projects in Ogba communities of rivers state, Nigeria, Global Approaches to Extension Practice, 4(1), 11-19. https://doi.org/10.4314/gaep.v4i1.34923

Sherrod, L. R., Flanagan, C., \& Youniss, J. (2002). Dimensions of citizenship and opportunities for youth development: The what, why, when, where and who of citizenship development. Applied Developmental Science, 6(4), $264-272$. https://doi.org/10.1207/S1532480XADS0604_14

Udensi, L. O., Daasi, G. L. K., Emah, D. S., \& Zukbee, S. A. (2013). Youth participation in community development (CD) programmes in cross river state: Implications for sustainable youth development in Nigeria. IOSR Journal of Humanities and Social Science (IOSR-JHSS), 13(5), 61-67.

Umeh, G. N., \& Odom, C. (2011). Role and constraints of youth associations in agricultural and rural development: evidence from Aguata L.G.A of Anambra State, Nigeria. World Journal of Agricultural Sciences, 7(5), 515-519. http://www.idosi.org/wjas/wjas7(5)/2.pdf

UNDP. (2018). Human development indices and indicators. New York: UNDP. http://hdr.undp.org/sites/default/ files/2018_summary_human_development_statistical_update_en.pdf 